\title{
Recent Progress in RXLR Effector Research
}

\author{
Ryan G. Anderson, Devdutta Deb, Kevin Fedkenheuer, and John M. McDowell \\ Department of Plant Pathology, Physiology, and Weed Science, Virginia Tech, Blacksburg, VA, U.S.A.
}

Submitted 31 January 2015. Accepted 9 June 2015.

\begin{abstract}
Some of the most devastating oomycete pathogens deploy effector proteins, with the signature amino acid motif RXLR, that enter plant cells to promote virulence. Research on the function and evolution of RXLR effectors has been very active over the decade that has transpired since their discovery. Comparative genomics indicate that RXLR genes play a major role in virulence for Phytophthora and downy mildew species. Importantly, gene-for-gene resistance against these oomycete lineages is based on recognition of RXLR proteins. Comparative genomics have revealed several mechanisms through which this resistance can be broken, most notably involving epigenetic control of RXLR gene expression. Structural studies have revealed a core fold that is present in the majority of RXLR proteins, providing a foundation for detailed mechanistic understanding of virulence and avirulence functions. Finally, functional studies have demonstrated that suppression of host immunity is a major function for RXLR proteins. Host protein targets are being identified in a variety of plant cell compartments. Some targets comprise hubs that are also manipulated by bacteria and fungi, thereby revealing key points of vulnerability in the plant immune network.
\end{abstract}

Much attention has been focused recently on oomycete RXLR effectors that are secreted to the interior of plant cells (Hogenhout et al. 2009). This area of study was launched in 2005 by a seminal paper that identified the RXLR motif based on its conservation in divergent oomycete avirulence proteins (Rehmany et al. 2005). This was followed by evidence that the RXLR motif mediates entry of effectors into host cells (Dou et al. 2008a; Whisson et al. 2007). At the same time, the RXLR motif played a central role in bioinformatic screens for candidate effector genes from three Phytophthora genomes (Haas et al. 2009; Tyler et al. 2006). Several RXLR effectors were shown to suppress plant immunity (Bos et al. 2006; Dou et al. 2008b; Kelley et al. 2010; Oh et al. 2009; Sohn et al. 2007), the first plant targets of RXLR proteins were identified (Bos et al. 2010; Senchou et al. 2004), and phospholipids were implicated as host membrane receptors for RXLR proteins (Kale et al. 2010), albeit with controversy. These and other aspects of RXLR effector biology have been discussed in several excellent reviews (Birch et al. 2009; de Jonge et al. 2011; Kale and Tyler 2011; Koeck et al. 2011; Pais et al. 2013; Schornack et al. 2009; Stassen and Van den Ackerveken 2011; Wawra et al. 2012). Our intent is to integrate the initial insights into RXLR biology with recent studies. We discuss evolution, structure, and function

Corresponding author: J. M. McDowell; E-mail: johnmcd@vt.edu; Telephone: +1.540 .231 .2388 .

(C) 2015 The American Phytopathological Society and include references to review papers that provide more detail about specific aspects of RXLR effector biology. We do not discuss mechanisms of RXLR host-cell entry or translational aspects of RXLR biology in detail, because these subjects have been covered in recent issues of MPMI and elsewhere (Du and Vleeshouwers 2014; Petre and Kamoun 2014; Tyler et al. 2013; Vleeshouwers and Oliver 2014; Wawra et al. 2013).

Comparative genomics suggests that RXLR genes

play a major role in virulence only

for Phytophthora and downy mildew species.

The first genome-wide inventories of RXLR genes were conducted in Phytophthora sojae, $P$. ramorum, and P. infestans (Haas et al. 2009; Jiang et al. 2008; Tyler et al. 2006). Since then, the collection of oomycete genomes has expanded dramatically. For example, 20 oomycete genomes now reside within Fungi DB. Altogether, these genomes encompass a wide range of taxonomy and lifestyle diversity within the oomycetes, ranging from the downy mildew and white rust pathogens that represent independent evolutions of obligate biotrophy to Pythium species that are canonical broad-host range necrotrophs (Fig. 1).

Analyses of these genomes have revealed proliferation of RXLR genes in Phytophthora species and downy mildew pathogens, which together comprise a major pathogenic lineage within the oomycetes (Fig. 1) (Thines and Kamoun 2010; Thines 2014)). Initial estimates of the size of the RXLR family in this lineage ranged from over 500 in Phytophthora infestans to approximately 130 in the Arabidopsis downy mildew pathogen Hyaloperonospora arabidopsidis (Jiang and Tyler 2012). However, evidence is accumulating to support the existence of RXLR variants, such as GKLR or QXLR (Asai et al. 2014; Bailey et al. 2011; Dou et al. 2008a; Kale et al. 2010; Stassen et al. 2013; Tian et al. 2011). These observations suggest that the downy mildew and Phytophthora species might possess even larger complements of RXLR (or "RXLR-like") effectors than initially predicted from conservative bioinformatic criteria.

In marked contrast to the Phytophthora and downy mildew lineage, other oomycete lineages appear to contain few or no RxLR genes. RXLR genes are absent from necrotrophs such as members of genus Pythium and the animal pathogens in the Saprolegnia genus (Adhikari et al. 2013; Jiang et al. 2013a; Krajaejun et al. 2011, 2014; Lévesque et al. 2010). The biotrophic white blister pathogens in the Albugo genus contain only a small number of putative RXLR genes, none of which have been functionally validated (Kemen et al. 2011; Links et al. 2011). Different classes of effectors are predominant in these lineages, including the CHXC class in genus Albugo and the broadly distributed Crinkler and YxSL[RK] superfamilies (Adhikari et al. 2013; Jiang and Tyler 2012; Kemen et al. 2011; Lévesque et al. 2010; Links et al. 2011). Thus, it appears that RXLR proteins are not important for virulence in all pathogenic 
oomycetes; rather, they have undergone a dramatic expansion in the Phytophthora and downy mildew lineage. This proliferation has been postulated as a key innovation during evolution of biotrophy in the ancestor of Phytophthora spp. and downy mildews (Jiang and Tyler 2012; Kemen and Jones 2012; McDowell 2011).

\section{Gene-for-gene resistance in oomycetes is based largely on recognition of RXLR proteins.}

Gene-for-gene resistance (also termed effector-triggered immunity [ETI]) is a critically important component of plant innate immunity and an important tool for management of crop diseases, including those caused by Albugo and Phytophthora spp. and downy mildew pathogens. A large sample of avirulence (Avr) genes have now been molecularly cloned (Table 1); almost every one of these genes encodes a protein with a canonical RXLR motif. The only exception, $H$. arabidopsidis Atr5, contains an EER motif that could be functionally equivalent to a canonical RXLR motif (Bailey et al. 2011). The near-ubiquity of the RXLR

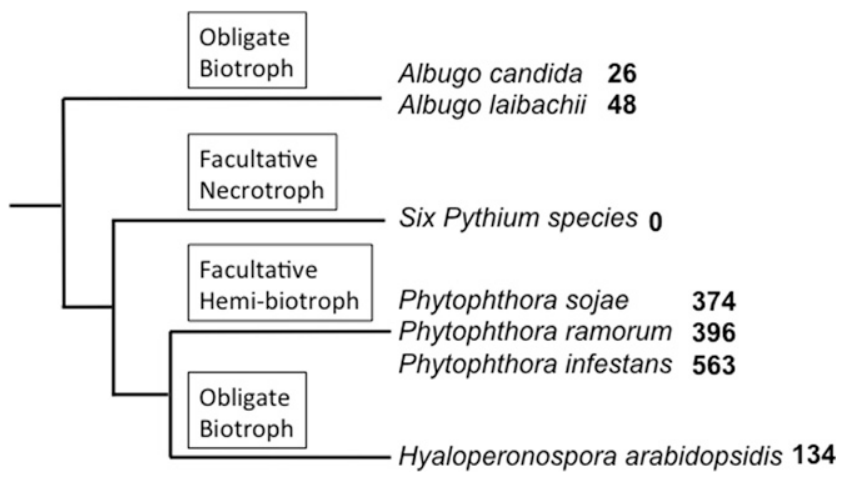

Fig. 1. Distribution of RXLR genes in oomycete lineages. The evolutionary relationships of oomycete pathogens with sequenced genomes is depicted by the tree. Host dependency and pathogenicity strategy of each lineage is summarized in the boxes. The number of predicted RXLR genes for each species is shown in bold. motif in oomycete Avr proteins is quite striking and, indeed, provided the basis for its identification (Rehmany et al. 2005). Despite the current controversy over the molecular function of the RXLR domain (Petre and Kamoun 2014; Tyler et al. 2013; Wawra et al. 2013), the prevalence of RXLR in Avr proteins leaves no doubt that this motif is critically important.

Another generality for oomycete gene-for-gene resistance is that the corresponding resistance $(R)$ genes encode nucleotidebinding, leucine rich repeat (NLR) proteins (Table 1). Most of these proteins contain a coiled-coil domain at the N-terminus. How are these immune surveillance proteins activated by RXLR effectors? The activation of RPP1 by Atr 1 from $H$. arabidopsidis involves direct physical interaction with a high degree of allelic specificity (Rehmany et al. 2005; Steinbrenner et al. 2015). In a contrasting case, the R2 NLR protein appears to recognize a complex comprised of the Avr2 RXLR protein and its putative target BSL2 (Saunders et al. 2012). Interestingly, a nonrecognized form of Avr2 can bind to BSL2 but is not capable of engagement of or with R2, suggesting that additional aspects of this interaction remain to be defined.

A couple of RXLR-NLR interactions exhibit interesting subcellular dynamics. The R1 and AvrR1 proteins localize to the nucleus and cytoplasm, and both proteins must be present in the nucleus to activate immunity (Du et al. 2015). This example follows others from bacterial and fungal effectors in which nuclear localization of the NLR is an important aspect of function. However, not all immune receptors operate within the nucleus. The NLR R3a resides in the nucleus and cytoplasm in its resting state but is relocalized to endosomal vesicles in the presence of the recognized form of Avr3a, which exhibits the same relocalization (Engelhardt et al. 2012). This relocalization is necessary for activation of resistance and does not occur in the presence of a nonrecognized form of Avr3a.

These examples presage the mechanistic complexity that likely underlies activation of ETI by RXLR proteins and highlight the need for more experimental focus on this area that is understudied for oomycete effectors, as compared with bacteria and fungi. The potential applied payoff lies in the prospect for engineering

Table 1. Cloned oomycete avirulence $(A v r)$ genes and corresponding plant resistance $(R)$ genes $^{\mathrm{a}}$

\begin{tabular}{|c|c|c|c|c|c|}
\hline Pathogen/Plant Avr Gene & Protein & Mutation $^{b}$ & $R$ gene & Protein ${ }^{c}$ & References \\
\hline \multicolumn{6}{|l|}{ Hyaloperonospora } \\
\hline Atrl & RXLR & $\mathrm{P}, \mathrm{D}$ & $R P P 1$ & TNL & Asai et al. 2014; Steinbrenner et al. 2015 \\
\hline Atr5 & RXLR-like? & $\mathrm{P}, \mathrm{D}$ & RPP5 & TNL & Bailey et al. 2011 \\
\hline Atr13 & RXLR & $\mathrm{P}$ & $R P P 13$ & $\mathrm{CNL}$ & Allen et al. 2004 \\
\hline Atr39 & RXLR & $\mathrm{P}, \mathrm{S} ?$ & $R P P 39$ & $\mathrm{CNL}$ & Goritschnig et al. 2012 \\
\hline \multicolumn{6}{|c|}{ Phytophthora infestans/Solanum species } \\
\hline Avrl & RXLR & & $R 1$ & $\mathrm{CNL}$ & Ballvora et al. 2002; Du et al. 2015 \\
\hline$A v r 2$ & RXLR & $\mathrm{P}, \mathrm{T}$ & $R 2$ & $\mathrm{CNL}$ & Gilroy et al. $2011 \mathrm{~b}$ \\
\hline$A v r 3 a$ & RXLR & $\mathrm{P}$ & $R 3 a$ & CNL & Armstrong et al. 2005 \\
\hline Avr4 & RXLR & $\mathrm{P}$ & $R 4$ & XNL? & van Poppel et al. 2008 \\
\hline$A v r B l b 2$ & RXLR & $\mathrm{P}, \mathrm{D}$ & $R p i-B l b 2$ & CNL & Oliva et al. 2015 \\
\hline$I P I-O$ & RXLR & $\mathrm{P}, \mathrm{S}$ & $R p i-B l b 1(R B)$ & $\mathrm{CNL}$ & Chen et al. 2012 \\
\hline AvrVnt1 & & $\mathrm{T}$ & Rpi-Vnt1 & $\mathrm{CNL}$ & Vleeshouwers et al. 2011 \\
\hline \multicolumn{6}{|c|}{ Phytophthora sojae/Glycine $\max$} \\
\hline Avrla & RXLR & $\mathrm{D}, \mathrm{T}$ & Rpsla, Rps1c & & Qutob et al. 2009; Na et al. 2014 \\
\hline$A v r 1 b-1$ & RXLR & $\mathrm{P}, \mathrm{T}$ & Rps $1 b$, Rps $1 k$ & & Shan et al. 2004 \\
\hline Avrlc & RXLR & $\mathrm{D}, \mathrm{T}$ & Rpslc & & $\mathrm{Na}$ et al. 2014 \\
\hline Avrld & RXLR & $\mathrm{D}$ & Rps1d & & Na et al. 2013; Yin et al. 2013 \\
\hline Avrlk & RXLR & $\mathrm{P}$ & Rps $1 k$ & CNL? & Gao and Bhattacharyya 2008; Song et al. 2013 \\
\hline$A v r 3 a / 5$ & RXLR & $\mathrm{P}, \mathrm{T}$ & Rps $3 a$, Rps 5 & & Qutob et al. 2009; Dong et al. 2011b \\
\hline$A v r 3 b$ & RXLR & $\mathrm{P}$ & $\operatorname{Rps} 3 b$ & & Dong et al. 2011a \\
\hline$A v r 3 c$ & RXLR & $\mathrm{P}$ & Rps $3 c$ & & Dong et al. 2009 \\
\hline Avr4/6 & RXLR & $\mathrm{T}$ & Rps4, Rps6 & XNL? & Dou et al. 2010 \\
\hline
\end{tabular}

a Adapted from tables published by Vleeshouwers et al. (2011) and Tyler and Gijzen (2014); blank cell = unknown.

b Mechanism through which resistance is evaded. $\mathrm{P}=$ point mutation; $\mathrm{D}=$ gene deletion; $\mathrm{T}=$ transcript reduction; $\mathrm{S}=$ suppression by another protein.

${ }^{\mathrm{c}} \mathrm{TNL}=$ toll interleukin 1 receptor-nucleo binding-leucine-rich repeat; $\mathrm{CNL}=$ coiled coil-nucleo binding-leucine-rich repeat; XNL $=\mathrm{N}$ terminal domain not specified; and ? = locus identified but exact gene not delineated. 
receptors with enhanced recognition (Dangl et al. 2013). Even with our relatively limited current understanding, promising initial steps toward this goal have been reported (Segretin et al. 2014).

\section{Oomycetes can defeat gene-for-gene resistance through a variety of mechanisms.}

Gene-for-gene resistance to oomycetes is often broken under field conditions (Fry 2008), implying that RXLR genes are highly mutable. Moreover, RXLR genes have been recently postulated as key factors in host range and nonhost resistance (Cooke et al. 2012; Lee et al. 2014; Raffaele et al. 2010; VegaArreguín et al. 2014). Thus, there is substantial interest in the genomic mechanisms that underpin RXLR gene evolution.

To begin with, the proliferation of RXLR genes in Phytophthora and downy mildew genomes suggests potential for functional redundancy. This could allow pathogens to discard deleterious RXLR genes (i.e., Avr genes) without a substantial fitness penalty. Interestingly, RXLR genes are predominantly located in genomic regions that contain relatively few genes and a high frequency of transposons and other repetitive elements. Contrastingly, housekeeping genes are located in gene-dense, repeat-sparse regions (Haas et al. 2009; Raffaele et al. 2010). This bipartite organization suggests a 'two-speed genome,' in which genes that support core functions reside in stable, slow-evolving regions of the genome, while effector genes are located in fastevolving regions of the genome to facilitate coevolution with the host (Raffaele and Kamoun 2012). Accordingly, genome-level comparisons of RXLR genes has provided evidence for diversifying selection, presence/absence polymorphisms and gene copy-number variation, intragenic recombination, and gene conversion (Jiang and Tyler 2012), recently exemplified by (Cooke et al. 2012; Goss et al. 2013; Na et al. 2014).

These DNA-level changes can defeat gene-for-gene resistance by deleting the Avr gene or altering the structure of the encoded protein so that it is not perceived by the host surveillance system. The potential complexity of these dynamics was illustrated by a study of the AvrBlb2 gene family in worldwide populations of $P$. infestans (Oliva et al. 2015). This survey identified four variants, one of which is not recognized by the $R$ gene $B l b 2$ that is currently being deployed for control of potato late blight (Vleeshouwers et al. 2011). Interestingly, pathogen populations maintained all four variants, perhaps because they are functionally diversified to provide differential fitness in different host environments.

Gene-for-gene resistance can also be defeated by expressionlevel polymorphisms in which the protein-coding sequence is intact but the gene is not transcribed (Table 1) (Cui et al. 2012; Gilroy et al. 2011b). In principle, this can be caused by DNA mutations that affect gene regulatory sequences. Moreover, recent studies suggest that variation in RXLR gene expression can be generated by epigenetic mechanisms (Kasuga and Gijzen 2013; Gijzen et al. 2014). Silenced epialleles of Avr genes from $P$. sojae and $P$. infestans have now been documented (Table 1); the most striking study demonstrated heritable silencing of the $P$. sojae Avr3a gene (Qutob et al. 2013). The mechanisms responsible for establishment, propagation, and release of silencing remain to be defined but, likely, involve either small RNAs, histone methylation, or both. Interestingly, the repeat- and effector-rich regions of the $P$. infestans genome are enriched for regulators of epigenetic processes (Raffaele and Kamoun 2012). The proximity of RXLR genes to transposable elements suggests a scenario in which epigenetic control of transposition might be co-opted to provide for global silencing of RXLR effector genes that could be reversed under conditions of environmental stress or jumps to a new host, to provide a much higher evolutionary potential than could be achieved via mutation alone (Gijzen et al. 2014; Kasuga and Gijzen 2013; Whisson et al. 2012).

Yet another strategy for defeating gene-for-gene resistance was suggested by analysis of the IPI-O effector, in which an allele for virulence interferes with detection of the avirulence allele by competitively binding the recognition domain on the cognate NLR surveillance protein (Chen et al. 2012). All together, these examples demonstrate that Phytophthora and downy mildew pathogens are truly artists of escape from genefor-gene resistance (Table 1). The varied mechanisms through which Avr effector genes are rendered nonfunctional will complicate strategies to detect resistance-breaking alleles in the field; it will be particularly challenging to develop facile assays for genes that are transcriptionally silenced.

\section{Structure of RXLR effector proteins reveals core motifs and a structural foundation for adaptability.}

Previous mutational studies have demonstrated that the RXLR domain does not contribute to the virulence function (Bos et al. 2006). Rather, the virulence function is provided by the C-terminal 'effector domain' (Schornack et al. 2009). Unfortunately, biochemical functions for $\mathrm{C}$-terminal regions have proven difficult to predict from primary sequence because the majority of RXLR effectors share little or no similarity with previously characterized proteins. This mirrors the situation with bacterial effectors. For this reason, three-dimensional structures of RXLR effector proteins have been eagerly anticipated in the hope of functional insights similar to those enabled by knowledge of the structure of bacterial effectors (Janjusevic et al. 2006).

Several RXLR effector structures have now been solved by $\mathrm{X}$-ray crystallography or nuclear magnetic resonance (NMR) (Win et al. 2012a). These structures do not contain the N-terminal RXLR domain, which is predicted to form a disordered structure. Rather, the structures were resolved from recombinant proteins in which the RXLR region was deleted. These structures highlight tertiary motifs in the $\mathrm{C}$-terminal effector domain that mediate effector activity and recognition by host surveillance proteins. For example, the $H$. arabidopsidis avirulence effector ATR1 consists of two, all-helical domains with a unique, tandemly duplicated five-helicase motif (Chou et al. 2011). ATR1 is recognized by the Arabidopsis NLR protein RPP1 (Krasileva et al. 2010; Rehmany et al. 2005). Key residues involved in the recognition of ATR 1 by two different RPP1 alleles were positioned on different surfaceexposed regions. This suggests that different alleles of RPP1 can recognize distinct surface regions of ATR1. Similarly, solution of the ATR13 structure by NMR revealed two patches of surfaceexposed polymorphism (Leonelli et al. 2011). Mutation experiments demonstrated that only one of these patches mediates recognition by the RPP13 resistance protein. No similarities to other proteins were found, but the structure did reveal a nucleolar localization signal that is an insertion and deletion polymorphism in the ATR13 sequence from different $H$. arabidopsidis isolates.

Structures have been solved for Phytophthora capsici Avr3a11, a homolog of P. infestans Avr3a and P. sojae Avr1b, and Phytophthora infestans PexRD2 (Boutemy et al. 2011). These proteins share less than $20 \%$ primary sequence identity; thus it is striking that 37 of the 64 residues from the monomeric PexRD2 structure align with the Avr3a11 monomeric structure. Importantly, both proteins share a core $\alpha$-helical fold called the WY domain, corresponding to motifs that had been previously identified in Phytophthora RXLR proteins based on primary sequence (Dou et al. 2008b; Jiang et al. 2008). Both structures reveal functionally important, polymorphic residues on the surface of the helix. Boutemy et al. (2011) predicted that this core fold is present in approximately $44 \%$ of Phytophthora RXLR effectors and approximately $26 \%$ of the $H$. arabidopsidis RXLR effectors. 
Many RXLR proteins contain repeats of the WY domain. Copy number variation in the WY domains has been documented for RXLR genes in P. ramorum (Goss et al. 2013). Based on variability observed within WY-containing regions, it is likely that the WY domain is an evolvable platform that can support polymorphism in surface residues, repeat copy-number variation, insertions with and between repeats, and oligomerization. Interestingly, the WY domain appears to be restricted to the Phytophthora and downy mildew lineages (Win et al. 2012a), suggesting that this fold was a key innovation during evolution of RXLR effectors in this lineage.

\section{Functional genomic studies suggest that a large proportion of RXLR proteins can suppress host immunity.}

The discovery of hundreds of potential RXLR proteins in Phytophthora genomes prompts the obvious questions of what their functions are and why so many. Important first steps toward addressing these questions at genomic scale have been taken by high-throughput studies in which effectors were transiently expressed inside plant cells. For example, Wang et al. (2011) assayed 169 RXLR effectors from the soybean pathogen Phytophthora sojae, using Agrobacterium-mediated transient expression in Nicotiana benthamiana. These genes were tested for their ability to suppress cell death elicited by the mammalian cell-death elicitor Bax, the oomycete elicitor INF1, or avirulence effectors from $P$. sojae. The majority of $P$. sojae RXLR effectors could suppress immune responses in this system, suggesting that a major function of the RXLR secretome is to sabotage plant immunity.

Another insight from the Wang et al. (2011) study is that the timing of RXLR gene expression could play an important role in oomycete virulence. Transcript profiling of $P$. sojae effector genes provided evidence for coordination, in which effectors expressed early in infection predominantly suppress ETI, while effectors expressed later in infection suppress pathogenassociated molecular pattern (PAMP)-triggered immunity (PTI) (Wang et al. 2011). This implies complex transcriptional programming to maximize virulence potential. Expression profiling in combination with analysis of allelic diversity suggests that a small number of highly expressed, polymorphic effectors may make the largest contributions to P. sojae virulence, while other, less abundantly expressed effectors may be dispensable. Additionally, the avirulence activities of some RXLR effectors can be suppressed by other RXLR effectors (Wang et al. 2011). This points to a strategy in which early-expressed effectors could act as 'bodyguards' to conceal essential effectors that possess avirulence activity but are indispensable for virulence.

Similar to the Wang et al. (2011) study, functional analysis of RXLR genes from Hyaloperonospora arabidopsidis by Fabro and colleagues (2011) revealed substantial capacity to suppress plant immunity. Because Agrobacterium-mediated transient assays do not work efficiently in Arabidopsis (Wroblewski et al. 2005), this study exploited Pseudomonas syringae as a surrogate pathogen to deliver RXLR proteins to Arabidopsis (Fabro et al. 2011). The screening system was based on an "effector detector vector' in which RXLR genes are fused to an N-terminal leader that guides the effector through the type III secretion system (Sohn et al. 2007). The screen also used strains of Pseudomonas constitutively expressing a luciferase reporter gene (Pst-LUX) for facile quantification of bacterial growth in planta. This system was used to test 64 predicted $H$. arabidopsidis RXLR effector genes by assaying for enhancement or reduction of growth in 12 different Arabidopsis accessions (ecotypes). Of the tested effectors, $70 \%$ enhanced Pst-LUX growth on multiple Arabidopsis ecotypes. This effect is likely attributable to the suppression of PTI, because the majority of effectors that increased bacterial growth also suppressed the accumulation of callose. Notably, few of the effectors were able to enhance Pst-LUX growth in all 12 screened Arabidopsis ecotypes, suggesting that their host targets may have diverged among Arabidopsis accessions. Expression of a subset of the $H$. arabidopsidis RXLR effectors in stably transformed plants recapitulated the results obtained via the Pst-LUX system. Only $22 \%$ of tested effectors could suppress PTI in turnip, a close relative of Arabidopsis but a nonhost for $H$. arabidopsidis, further suggesting that most of the effectors are optimized for their host targets.

Other screening methods have been employed to yield additional interesting results. Perhaps the simplest was to screen bioinformatically for 'core' RXLR genes that are conserved between downy mildew pathogens and Phytophthora species. Only a handful were found (Baxter et al. 2010). Comparative functional analysis of one pair of homologous effectors from $H$. arabidopsidis and $P$. sojae revealed that both effectors can suppress one or both ETI and PTI in soybean, $N$. benthamiana, and Arabidopsis (Anderson et al. 2012). It will be of interest to determine whether conserved effectors target homologous proteins in these divergent hosts.

Transgenic plants overexpressing effector genes have been critically important for understanding the functions of bacterial effectors (Munkvold and Martin 2009). This approach was used to delineate virulence contributions of $H$. arabidopsidis RXLR genes (Pel et al. 2014). A creative alternative was devised by Badel et al. (2013), in which mixed pools of bacteria with different $H$. arabidopsidis RXLR effectors were inoculated into Arabidopsis leaves and the relative success of each strain was measured 3 days later by high throughput sequencing or capillary electrophoresis. This 'effector competition assay' provided an estimate of the contribution of each effector to virulence (Badel et al. 2013). Data from both of these studies support the concept that RXLR effectors make quantitative contributions by acting at multiple levels in the immune network.

Additional creative approaches were used in medium-throughput screens for effectors that target specific plant pathways. One screen was for RXLR proteins that suppress responses to the bacterial PAMP flg22 (Zheng et al. 2014). In this system, P. infestans RXLR effector genes were transiently transfected into tomato protoplasts containing a flg22-responsive promoter fused to the luciferase reporter. This screen revealed RXLR effectors that suppress PTI at different steps in the signaling hierarchy. Interestingly, several effectors suppressed PTI in both tomato and Arabidopsis (Zheng et al. 2014). A similar screen utilized stably transformed plants overexpressing RXLR genes to screen specifically for effectors that interfere with salicylic acid (SA)-responsive gene induction. Nine RXLR genes from $H$. arabidopsidis were screened for suppression of SA-inducible PR-1 transcription and one (HaRxL62) demonstrated this capacity (Asai et al. 2014).

Another important question concerns the subcellular localization of effectors in planta. Caillaud (2012) examined subcellular localization of $49 \mathrm{H}$. arabidopsidis RXLR-GFP (green fluorescent protein) fusions, expressed from stably transformed Arabidopsis. The majority of effectors targeted either the nucleus or host membranes. Some cellular components were not targeted, including the mitochondria or chloroplast, and little correlation was found between predicted subcellular localization and observed localization. Allelic polymorphisms in localization were identified for several effectors. Importantly, relocalization during $H$. arabidopsidis infections of stably transformed GFP-effector fusions was also observed. For example, HaRxL17 displays a unique subcellular address at the host tonoplast and is the first oomycete effector known to associate with this compartment (Fig. 2). During H. arabidopsidis infection, GFP-HaRxL17 fusions relocalized to the haustoria. This study highlights the utility of live-cell imaging of infected tissue for understanding RXLR effector function. 


\section{Interactome studies reveal protein complexes} convergently targeted by oomycetes, fungi, and bacteria.

High-throughput strategies have also been used to identify candidate protein targets of RXLR effectors. A landmark report described a large-scale yeast two-hybrid screen for targets of 99 RXLR effector proteins from $H$. arabidopsidis and 53 type III effectors from Pseudomonas syringae (Mukhtar et al. 2011). These effectors were screened against a library comprising three classes of Arabidopsis immune proteins: i) N-terminal regions from NLR surveillance proteins, ii) cytoplasmic domains from leucine-rich repeat-receptor line kinases, and iii) known defense proteins. Additionally, the effectors were screened against approximately 8,000 Arabidopsis proteins that comprised version 1 of the Arabidopsis interactome described in a companion study (AI-1) (Arabidopsis Interactome Mapping 2011). Finally, the immune proteins were tested for interaction with each other and with the AI-1 set.

The interactions from this screen were combined with literaturecurated interactions to generate a network that predicts interaction of 165 plant proteins with 53 RXLR effectors and 30 type III effectors (Mukhtar et al. 2011). This network supports a key prediction of the guard model, which states that independently evolved plant pathogens will have common defense-related host targets. A total of 18 plant proteins interacted with effectors from both pathogens; loss-of-function mutants in 15 of 17 of these displayed altered immunity, suggesting that they are bona fide target proteins.

A subsequent publication extended the evidence for convergent targeting to the fungal, obligate biotrophic fungal pathogen Golovinomyces orontii (Wessling et al. 2014). A total of 63 effector proteins were screened against 12,000 Arabidopsis proteins. These data were integrated with the interactions documented by Mukhtar et al. (2011) to provide the first plant-pathogen interactome encompassing bacterial, fungal, and oomycete pathogens. Nine Arabidopsis proteins interacted with effectors from all three pathogens and another 23 interacted with effectors from two pathogens. Loss-of-function mutants in 123 candidate target genes were tested with all three pathogens, including three different isolates of $H$. arabidopsidis. Interestingly, the three $H$. arabidopsidis isolates interacted differentially with a number of mutants, including opposite phenotypes for several (i.e., enhanced disease resistance versus enhanced disease susceptibility). This suggests intraspecific polymorphism in the effectors and their targets.

The results of the interaction survey combined with simulation studies suggest general properties of effectors. Effectors from all three pathogens collectively converge onto a set of proteins that likely comprise points of vulnerability in the immune network. Effectors preferentially target highly connected proteins, perturbation of which is more likely to destabilize the associated network. Finally, a substantial proportion of effector targets also interact with NLR proteins, suggestive of guarding. Some targets interact with many effectors, suggesting that they are under massive attack (e.g., the AtTCP14 protein interacts with 29 effectors), and some effectors interact with several plant proteins, suggesting that these saboteurs have multiple targets. This dataset represents a treasure trove for future studies and presages the complexity of host cell manipulation by RXLR proteins. This complexity is further underscored by mechanistic analysis of RXLR proteins that are summarized in the following section.

\section{RXLR effectors target a diverse array of pathways within the host cell.}

As mentioned above, very few oomycete effector sequences possess recognizable motifs or domains. One exception is $P$. sojae Avr3b, which contains a Nudix motif with ADP-ribose/NADH pyrophosphorylase activity (Dong et al. 2011a). Avr3b is essential for full $P$. sojae virulence in susceptible soybean. When expressed as a transgene, Avr3b enhances host susceptibility to two other oomycete pathogens. Mutations in the Avr3b Nudix motif established the importance of ADP-ribose/NADH pyrophosphorylase activity and suggested a link to suppression of reactive oxygen species (ROS) (Fig. 2). However, ADP-ribose/NADH pyrophosphorylase activity is not necessary for recognition by the cognate $\mathrm{R}$ protein. The exact link between immune suppression and the Nudix motif remains to be elucidated but might involve either reduction of NADH levels, recycling nucleosides from ADPribose, or both, consequently reducing the accumulation of ROS.

Another RXLR effector with a recognizable functional motif is IPI-O from $P$. infestans. The motif RGD is associated with integrins, a class of membrane-spanning receptors that mediate cell adhesion. RGD motifs are also found in proteins that bind to and antagonize integrins, and RGD peptides are known to disrupt adhesions between the plasma membranes and walls of plant cells. Accordingly, IPI-O was shown to disrupt these adhesions, in part by targeting the Arabidopsis lectin receptor kinase LecRK-I.9 (Bouwmeester et al. 2011; Senchou et al. 2004). Genetic experiments revealed the importance of LecRK1.9 for resistance of Arabidopsis to Phytophthora brassicae (Bouwmeester et al. 2011). These studies underscore the importance of the plasma membrane-cell wall continuum in immunity and reinforce the notion that the pathogen-plant plasma membrane interface is an active battleground. Interestingly, LecRK-I.9 was recently demonstrated to be the receptor for extracellular ATP (Choi et al. 2014), and it will be interesting to follow up on this connection in the context of plant-oomycete interactions.

Avrblb2 from $P$. infestans is a second effector that operates spatially at the plant-pathogen interface. Live-cell imaging was used to demonstrate that Avrblb2 relocalizes from the plant plasma membrane in uninfected plant cells to the haustorial interface in infected cells (Bozkurt et al. 2011) (Fig. 2). A proteomic screen for Avrblb2 host targets revealed the secreted papain-like cysteine protease $\mathrm{C} 14$, which is present in diverse plant species. The relevance of this interaction was verified by

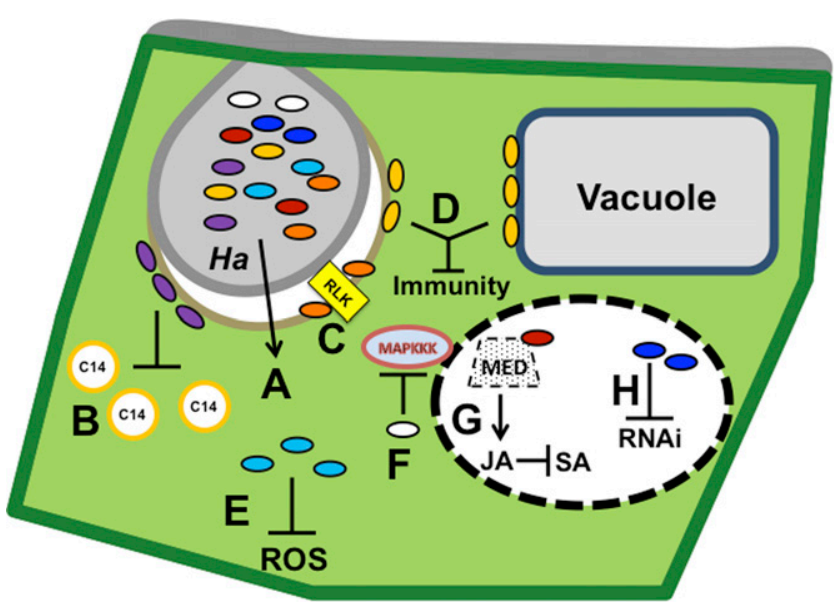

Fig. 2. Oomycete RXLR effectors target diverse processes and cellular compartments to suppress immunity. A, RXLR effectors enter host cells and localize to distinct compartments. B, Avrblb2 inhibits secretion of the C14 protease at the haustorial interface. C, IPI-O disrupts plasma membrane-cell wall adhesions, in part through interaction with a host receptor-like kinase. D, HaRxL17 exerts its virulence activity at either the tonoplast, region surrounding the haustoria in infected cells, or both. E, Avr3b utilizes a Nudix motif to reduce production of reactive oxygen species. F, PexRD2 interacts with mitogen-activated protein kinase kinase kinase epsilon. G, HaRxL44 destabilizes the transcriptional regulator MED19a in the nucleus to activate jasmonic acid signaling and, thereby, suppress salicylic acid-mediated immune responses. H, Phytophthora sojae PSR1 targets host RNA interference by interacting with an aspartateglutamate-alanine-histidine box RNA helicase domain protein, which likely affects assembly of dicing complexes. 
experiments demonstrating that Avrblb2 interferes with secretion of $\mathrm{C} 14$ to the apoplast. How Avrblb2 specifically inhibits C14 secretion remains to be described. Interestingly, C14 is also targeted by two unrelated non-RXLR apoplastic oomycete effectors (Kaschani et al. 2010), suggesting that the C14 is an important target for $P$. infestans.

A different mode of spatial interference was recently revealed for the $P$. infestans effector Pi03192 (McLellan et al. 2013). This effector interacts with two NAC transcription factors that positively regulate immune responses to $P$. infestans culture filtrate and are genetically necessary for basal resistance to $P$. infestans in $N$. benthamiana. Both proteins relocalize from the endoplasmic reticulum to the nucleus following treatment with culture filtrate. Pi03192 interferes with this relocalization; the mechanism is yet to be determined.

The $P$. infestans RXLR effector Avr3a alters the localization and proteasome-mediated turnover of the plant immune regulator CMPG1 (Bos et al. 2010). This link to the proteasome mirrors bacterial effectors that manipulate the stability of their targets. A recent study linked CMPG1 with perception of pathogen signals at the plasma membrane; resistance mediated by cytoplasmic NLR proteins does not require CMPG1 (Gilroy et al. 2011a). A structure and function study of Avr3a identified a positively charged patch of amino acids in the $\mathrm{C}$-terminal domain that mediates binding to phosphatidylinositol monophosphates (PIPs), in particular, phosphatidylinositol 3-phosphate (Yaeno et al. 2011). The ability of Avr3a to bind PIPs is not necessary for recognition by the cognate resistance protein R3a but is necessary for Avr3a virulence functions, including suppression of immune responses and stabilization of CMPG1. The mechanistic link between PIP binding and virulence functions remains unresolved. The most likely scenario is that Avr3a interacts with PIPs to target vesicular CMPG1 and to relocalize CMPG1 to the nucleus, thereby altering signaling cascades that originate at the plasma membrane (Fig. 2).

Mitogen-activated protein kinase (MAPK) pathways are important components of the immune network and are extensively targeted by bacterial pathogens (Feng and Zhou 2012). A twohybrid screen revealed that $P$. infestans PexRD2 (discussed above) directly interacts with MAPK kinase kinase (MAPKKK) epsilon. This study elegantly leveraged the PexRD2 structure to identify key residues mediating the interaction. Interestingly, PexRD2related-proteins do not target MAPKKK epsilon, thus providing a case study of how effector target specificity can evolve. It will be of great interest to better understand the mechanistic consequences of this interaction. Which pathways are altered and does the alteration result from direct manipulation of the putative target? As the authors note, it is conceivable that MAPKKK epsilon could phosphorylate PexRD2 and thereby act as the effector's 'accomplice,' rather than its target per se (Win et al. 2012b).

Qiao and colleagues searched for RXLR effectors that suppress host RNA silencing (Qiao et al. 2013). This screen identified two such effectors, PSR1 and PSR2, and set the stage for a better understanding of how RNA silencing mediates immunity to oomycetes (Wong et al. 2014). Interestingly, these effectors are conserved in the Phytophthora genus and can suppress RNA silencing in two distantly related species (Xiong et al. 2014). A target of PSR1, called PINP1, was recently identified as an aspartate-glutamate-alanine-histidine-box RNA helicase domain protein (Qiao et al. 2015). This protein is likely involved in regulation of small RNA accumulation as a component of the Dicer complex and is necessary for plant development and regulation of immunity. Importantly, this protein had not been previously associated with RNA interference.

Another possible example of RXLR-mediated interference with host posttranscriptional regulation was provided by P. infestans RXLR effector Pi04089. This protein interacts with a putative RNA binding protein from potato (StKRBP1) that contains a K-homology domain (Wang et al. 2015). The molecular function of StKRBP1 remains to be determined, but it was clearly validated as an important factor contributing to successful infection by P. infestans. As with PNP1, the function of StKRBP1 had not been investigated prior to its identification as a pathogen-targeted protein; thus, the examples of PNP1 and StKRBP1 underscore how effectors can lead to important but understudied host regulatory proteins and pathways (Win et al. $2012 \mathrm{~b}$ ). This is a major rationale to continue with mechanistic studies of RXLR proteins in diverse pathosystems.

\section{Hormone signaling pathways are a major target of RXLR effectors.}

Multiple lines of evidence have indicated that manipulation of plant hormone signaling is a major strategy of oomycete pathogens. Now, several effectors have been linked with hormone responses. Two of these, HaRxL62 and HaRxL44 from $H$. arabidopsidis, manipulate host responsiveness to the hormone SA, which is a key positive regulator of immunity. HaRxL62 was identified in the screen for suppression of SA-responsive gene described above (Asai et al. 2014); its target remains to be identified. In the case of HaRxL44, a target was identified in PPIN-1 and a sophisticated mechanism has been revealed. This effector targets a specific subunit of the mediator transcription complex. The MED19a protein is engaged by HaRxL44, resulting in proteasome-dependent degradation. Importantly, loss of MED19a activates jasmonic acid (JA)-responsive gene expression that, in turn, suppresses SA-responsive gene expression. Thus, it appears that $H$. arabidopsidis can exploit JA-SA antagonism in a manner similar to but distinct from $P$. syringae, which activates the JA signaling sector with the JA mimic coronatine and two different type III effectors (Gimenez-Ibanez et al. 2014; Jiang et al. 2013b; Thines et al. 2007).

RXLR proteins have also been linked to brassinosteroid (BR) and auxin responses. The link to BR occurs via the aforementioned P. infestans Avr2 protein, which interacts with BLS2 proteins from solanaceous species (Saunders et al. 2012). BLS2 proteins are related to the Arabidopsis BR response regulator BSU1. The Avr2-BLS2 interaction is important for recognition mediated by the R2 immune surveillance protein (Saunders et al. 2012), but its significance for $P$. infestans virulence has not been established. A link to auxin responses was provided by analysis of penetration-specific effector 1 (PSE1) from Phytophthora parasitica (Evangelisti et al. 2013). Like many effectors, PSE1 suppresses immune responses and enhances susceptibility. However, this effector also causes auxin-related phenotypes when overexpressed in Arabidopsis and reduces auxin concentrations in roots infected by $P$. parasitica. Notably, auxin efflux proteins were mislocalized in PSE1-overexpressing plants, suggesting that the effector perturbs auxin responses by interfering with transport. In this way, there is commonality between oomycete, bacterial (Cui et al. 2013), and nematode effectors (Lee et al. 2011) in terms of auxin perturbation.

\section{Conclusions.}

We hope to have conveyed that exciting advances in understanding of RXLR effector biology have been reported in recent years. Challenging but important questions will provide foci in the longer term. What is the complete set of operative targets of RXLR effectors in a host plant, and how does the composition of this set vary between pathosystems? Do RXLR effectors perform sophisticated molecular functions that mimic plant proteins, or might some simply bind to plant protein complexes and thereby disrupt function? How are RXLR effector gene expression and protein secretion regulated, and how does this impact virulence? How many RXLR effectors are essential for virulence by stringent genetic criteria, and how does 
the set of essential effectors vary among pathogens? Do RXLR effectors cooperate with each other or other types of effectors, and if so, is it possible to identify emergent properties resulting from effector cooperation? Can we develop a systems-level understanding of effector manipulations of the host (Pritchard and Birch 2011). Answers to each of these questions will inform the ultimate goal of oomycete research, which is to develop new tools to support durable, low-input control of oomycete diseases.

\section{NOTE ADDED IN PROOF:}

Readers of this article might also be interested in the current state of knowledge about effector proteins from plant-associated fungi, summarized nicely by L. L. Presti, L. Lanver, G., Schweizer, S. Tanaka, L. Liang, M. Tollot, A. Zuccaro, S. Reissmann, and R. Kahmann in an article titled "Fungal Effectors and Plant Susceptibility" (Ann. Rev. Plant Biol. 66:513-545).

\section{ACKNOWLEDGMENTS}

We thank B. Vinatzer and S. Y. He for comments on the manuscript. Support was provided by the National Science Foundation (IOS-0744875 and IOS-1353366) and the United States Department of Agriculture National Institute of Food and Agriculture (2009-03008 and 2011-68004).

\section{LITERATURE CITED}

Adhikari, B. N., Hamilton, J. P., Zerillo, M. M., Tisserat, N., Lévesque, C. A., and Buell, C. R. 2013. Comparative genomics reveals insight into virulence strategies of plant pathogenic oomycetes. PLoS ONE 8:e75072.

Allen, R. L., Bittner-Eddy, P. D., Grenvitte-Briggs, L. J., Meitz, J. C., Rehmany, A. P., Rose, L. E., and Beynon, J. L. 2004. Host-parasite coevolutionary conflict between Arabidopsis and downy mildew. Science 306:1957-1960.

Anderson, R. G., Casady, M. S., Fee, R. A., Vaughan, M. M., Deb, D., Fedkenheuer, K., Huffaker, A., Schmelz, E. A., Tyler, B. M., and McDowell, J. M. 2012. Homologous RXLR effectors from Hyaloperonospora arabidopsidis and Phytophthora sojae suppress immunity in distantly related plants. Plant J. 72:882-893.

Arabidopsis Interactome Mapping Consortium. 2011. Evidence for network evolution in an Arabidopsis interactome map. Science 333:601-607.

Armstrong, M. R., Whisson, S. C., Pritchard, L., Bos, J. I., Venter, E., Avrova, A. O., Rehmany, A. P., Böhme, U., Brooks, K., Cherevach, I., Hamlin, N., White, B., Fraser, A., Lord, A., Quail, M. A., Churcher, C., Hall, N., Berriman, M., Huang, S., Kamoun, S., Beynon, J. L., and Birch, P. R. 2005. An ancestral oomycete locus contains late blight avirulence gene $A v r 3 a$, encoding a protein that is recognized in the host cytoplasm. Proc. Natl. Acad. Sci. U.S.A. 102:7766-7771.

Asai, S., Rallapalli, G., Piquerez, S. J., Caillaud, M. C., Furzer, O. J., Ishaque, N., Wirthmueller, L., Fabro, G., Shirasu, K., and Jones, J. D. 2014. Expression profiling during Arabidopsis/downy mildew interaction reveals a highly-expressed effector that attenuates responses to salicylic acid. PLoS Pathog. 10:e1004443.

Badel, J. L., Piquerez, S. J., Greenshields, D., Rallapalli, G., Fabro, G., Ishaque, N., and Jones, J. D. 2013. In planta effector competition assays detect Hyaloperonospora arabidopsidis effectors that contribute to virulence and localize to different plant subcellular compartments. Mol. Plant-Microbe Interact. 26:745-757.

Bailey, K., Cevik, V., Holton, N., Byrne-Richardson, J., Sohn, K. H., Coates, M., Woods-Tör, A., Aksoy, H. M., Hughes, L., Baxter, L., Jones, J. D., Beynon, J., Holub, E. B., and Tör, M. 2011. Molecular cloning of ATR5(Emoy2) from Hyaloperonospora arabidopsidis, an avirulence determinant that triggers RPP5-mediated defense in Arabidopsis. Mol. Plant-Microbe Interact. 24:827-838.

Ballvora, A., Ercolano, M. R., Weiss, J., Meksem, K., Bormann, C. A. Oberhagemann, P., Salamini, F., and Gebhardt, C. 2002. The $R 1$ gene for potato resistance to late blight (Phytophthora infestans) belongs to the leucine zipper/NBS/LRR class of plant resistance genes. Plant J. 30: 361-371.

Baxter, L., Tripathy, S., Ishaque, N., Boot, N., Cabral, A., Kemen, E., Thines, M., Ah-Fong, A., Anderson, R., Badejoko, W., Bittner-Eddy, P., Boore, J. L., Chibucos, M. C., Coates, M., Dehal, P., Delehaunty, K., Dong, S., Downton, P., Dumas, B., Fabro, G., Fronick, C., Fuerstenberg, S. I., Fulton, L., Gaulin, E., Govers, F., Hughes, L., Humphray, S., Jiang, R. H., Judelson, H., Kamoun, S., Kyung, K., Meijer, H., Minx, P., Morris,
P., Nelson, J., Phuntumart, V., Qutob, D., Rehmany, A., RougonCardoso, A., Ryden, P., Torto-Alalibo, T., Studholme, D., Wang, Y., Win, J., Wood, J., Clifton, S. W., Rogers, J., Van den Ackerveken, G., Jones, J. D., McDowell, J. M., Beynon, J., and Tyler, B. M. 2010. Signatures of adaptation to obligate biotrophy in the Hyaloperonospora arabidopsidis genome. Science 330:1549-1551

Birch, P. R., Armstrong, M., Bos, J., Boevink, P., Gilroy, E. M., Taylor, R. M., Wawra, S., Pritchard, L., Conti, L., Ewan, R., Whisson, S. C., van West, P., Sadanandom, A., and Kamoun, S. 2009. Towards understanding the virulence functions of RXLR effectors of the oomycete plant pathogen Phytophthora infestans. J. Exp. Bot. 60:1133-1140.

Bos, J. I., Armstrong, M. R., Gilroy, E. M., Boevink, P. C., Hein, I., Taylor, R. M., Zhendong, T., Engelhardt, S., Vetukuri, R. R., Harrower, B., Dixelius, C., Bryan, G., Sadanandom, A., Whisson, S. C., Kamoun, S., and Birch, P. R. 2010. Phytophthora infestans effector AVR3a is essential for virulence and manipulates plant immunity by stabilizing host E3 ligase CMPG1. Proc. Natl. Acad. Sci. U.S.A. 107:9909-9914.

Bos, J. I. B., Kanneganti, T. D., Young, C., Cakir, C., Huitema, E., Win, J., Armstrong, M. R., Birch, P. R., and Kamoun, S. 2006. The C-terminal half of Phytophthora infestans RXLR effector AVR3a is sufficient to trigger R3a-mediated hypersensitivity and suppress INF1-induced cell death in Nicotiana benthamiana. Plant J. 48:165-176.

Boutemy, L. S., King, S. R., Win, J., Hughes, R. K., Clarke, T. A., Blumenschein, T. M., Kamoun, S., and Banfield, M. J. 2011. Structures of Phytophthora RXLR effector proteins: A conserved but adaptable fold underpins functional diversity. J. Biol. Chem. 286:35834-35842.

Bouwmeester, K., de Sain, M., Weide, R., Gouget, A., Klamer, S., Canut, H., and Govers, F. 2011. The lectin receptor kinase LecRK-I.9 is a nove Phytophthora resistance component and a potential host target for a RXLR effector. PLoS Pathog. 7:e1001327.

Bozkurt, T. O., Schornack, S., Win, J., Shindo, T., Ilyas, M., Oliva, R., Cano, L. M., Jones, A. M. E., Huitema, E., van der Hoorn, R. A. L., and Kamoun, S. 2011. Phytophthora infestans effector AVRblb2 prevents secretion of a plant immune protease at the haustorial interface. Proc. Natl. Acad. Sci. 108:20832-20837.

Caillaud, M.-C., Piquerez, S. J. M., Fabro, G., Steinbrenner, J., Ishaque, N., Beynon, J., and Jones, J. D. G. 2012. Subcellular localization of the Hpa RxLR effector repertoire identifies the extrahaustorial membranelocalized HaRxL17 that confers enhanced plant susceptibility. Plant J. 69:252-265.

Chen, Y., Liu, Z., and Halterman, D. A. 2012. Molecular determinants of resistance activation and suppression by Phytophthora infestans effector IPI-O. PLoS Pathog. 8:e1002595.

Choi, J., Tanaka, K., Cao, Y., Qi, Y., Qiu, J., Liang, Y., Lee, S. Y., and Stacey, G. 2014. Identification of a plant receptor for extracellular ATP. Science 343:290-294.

Chou, S., Krasileva, K. V., Holton, J. M., Steinbrenner, A. D., Alber, T., and Staskawicz, B. J. 2011. Hyaloperonospora arabidopsidis ATR1 effector is a repeat protein with distributed recognition surfaces. Proc. Natl. Acad. Sci. U.S.A. 108:13323-13328.

Cooke, D. E., Cano, L. M., Raffaele, S., Bain, R. A., Cooke, L. R., Etherington, G. J., Deahl, K. L., Farrer, R. A., Gilroy, E. M., Goss, E. M., Grünwald, N. J., Hein, I., MacLean, D., McNicol, J. W., Randall, E., Oliva, R. F., Pel, M. A., Shaw, D. S., Squires, J. N., Taylor, M. C., Vleeshouwers, V. G., Birch, P. R., Lees, A. K., and Kamoun, S. 2012. Genome analyses of an aggressive and invasive lineage of the Irish potato famine pathogen. PLoS Pathog. 8:e1002940.

Cui, F., Wu, S., Sun, W., Coaker, G., Kunkel, B., He, P., and Shan, L. 2013. The Pseudomonas syringae type III effector AvrRpt 2 promotes pathogen virulence via stimulating Arabidopsis auxin/indole acetic acid protein turnover. Plant Physiol. 162:1018-1029.

Cui, L., Yin, W., Dong, S., and Wang, Y. 2012. Analysis of polymorphism and transcription of the effector gene Avrlb in Phytophthora sojae isolates from China virulent to Rps1b. Mol. Plant Pathol. 13:114-122.

Dangl, J. L., Horvath, D. M., and Staskawicz, B. J. 2013. Pivoting the plant immune system from dissection to deployment. Science 341:746-751.

de Jonge, R., Bolton, M. D., and Thomma, B. P. H. J. 2011. How filamentous pathogens co-opt plants: The ins and outs of fungal effectors. Curr. Opin. Plant Biol. 14:400-406.

Dong, S., Qutob, D., Tedman-Jones, J., Kuflu, K., Wang, Y., Tyler, B. M., and Gijzen, M. 2009. The Phytophthora sojae avirulence locus Avr3c encodes a multi-copy RXLR effector with sequence polymorphisms among pathogen strains. PLoS ONE 4:e5556.

Dong, S., Yin, W., Kong, G., Yang, X., Qutob, D., Chen, Q., Kale, S. D., Sui, Y., Zhang, Z., Dou, D., Zheng, X., Gijzen, M., Tyler, B. M., and Wang, Y. 2011a. Phytophthora sojae avirulence effector Avr3b is a secreted NADH and ADP-ribose pyrophosphorylase that modulates plant immunity. PLoS Pathog. 7:e1002353. 
Dong, S., Yu, D., Cui, L., Qutob, D., Tedman-Jones, J., Kale, S. D., Tyler, B. M., Wang, Y., and Gijzen, M. 2011b. Sequence variants of the Phytophthora sojae RXLR effector Avr3a/5 are differentially recognized by Rps3a and Rps5 in soybean. PLoS ONE 6:e20172.

Dou, D., Kale, S. D., Liu, T., Tang, Q., Wang, X., Arredondo, F. D. Basnayake, S., Whisson, S., Drenth, A., Maclean, D., and Tyler, B. M. 2010. Different domains of Phytophthora sojae effector Avr4/6 are recognized by soybean resistance genes Rps4 and Rps6. Mol. PlantMicrobe Interact. 23:425-435.

Dou, D., Kale, S. D., Wang, X., Chen, Y., Wang, Q., Wang, X., Jiang, R. H., Arredondo, F. D., Anderson, R. G., Thakur, P. B., McDowell, J. M., Wang, Y., and Tyler, B. M. 2008b. Conserved C-terminal motifs required for avirulence and suppression of cell death by Phytophthora sojae effector Avr1b. Plant Cell 20:1118-1133.

Dou, D., Kale, S. D., Wang, X., Jiang, R. H., Bruce, N. A., Arredondo, F. D., Zhang, X., and Tyler, B. M. 2008a. RXLR-mediated entry of Phytophthora sojae effector Avrlb into soybean cells does not require pathogen-encoded machinery. Plant Cell 20:1930-1947.

Du, J., and Vleeshouwers, V. G. 2014. The do's and don'ts of effectoromics. Methods Mol. Biol. 1127:257-268.

Du, Y., Berg, J., Govers, F., and Bouwmeester, K. 2015. Immune activation mediated by the late blight resistance protein $\mathrm{R} 1$ requires nuclear localization of R1 and the effector AVR1. New Phytol. Online 1207: 735-747.

Engelhardt, S., Boevink, P. C., Armstrong, M. R., Ramos, M. B., Hein, I., and Birch, P. R. J. 2012. Relocalization of late blight resistance protein $\mathrm{R} 3 \mathrm{a}$ to endosomal compartments is associated with effector recognition and required for the immune response. Plant Cell 24:5142-5158.

Evangelisti, E., Govetto, B., Minet-Kebdani, N., Kuhn, M. L., Attard, A., Ponchet, M., Panabières, F., and Gourgues, M. 2013. The Phytophthora parasitica RXLR effector penetration-specific effector 1 favours Arabidopsis thaliana infection by interfering with auxin physiology. New Phytol. 199:476-489.

Fabro, G., Steinbrenner, J., Coates, M., Ishaque, N., Baxter, L., Studholme, D. J., Körner, E., Allen, R. L., Piquerez, S. J., Rougon-Cardoso, A. Greenshields, D., Lei, R., Badel, J. L., Caillaud, M. C., Sohn, K. H., Van den Ackerveken, G., Parker, J. E., Beynon, J., and Jones, J. D. 2011. Multiple candidate effectors from the oomycete pathogen Hyaloperonospora arabidopsidis suppress host plant immunity. PLoS Pathog. 7: e1002348.

Feng, F., and Zhou, J.-M. 2012. Plant-bacterial pathogen interactions mediated by type III effectors. Curr. Opin. Plant Biol. 15:469-476.

Fry, W. 2008. Phytophthora infestans: The plant (and $R$ gene) destroyer. Mol. Plant Pathol. 9:385-402.

Gao, H., and Bhattacharyya, M. K. 2008. The soybean-Phytophthora resistance locus Rps l-k encompasses coiled coil-nucleotide bindingleucine rich repeat-like genes and repetitive sequences. BMC Plant Biol. 8:29.

Gijzen, M., Ishmael, C., and Shrestha, S. D. 2014. Epigenetic control of effectors in plant pathogens. Front. Plant Sci. 5:638.

Gilroy, E. M., Breen, S., Whisson, S. C., Squires, J., Hein, I., Kaczmarek, M., Turnbull, D., Boevink, P. C., Lokossou, A., Cano, L. M., Morales, J., Avrova, A. O., Pritchard, L., Randall, E., Lees, A., Govers, F., van West, P., Kamoun, S., Vleeshouwers, V. G., Cooke, D. E., and Birch, P. R. 2011b. Presence/absence, differential expression and sequence polymorphisms between PiAVR2 and PiAVR2-like in Phytophthora infestans determine virulence on R2 plants. New Phytol. 191:763-776.

Gilroy, E. M., Taylor, R. M., Hein, I., Boevink, P., Sadanandom, A., and Birch, P. R. 2011a. CMPG1-dependent cell death follows perception of diverse pathogen elicitors at the host plasma membrane and is suppressed by Phytophthora infestans RXLR effector AVR3a. New Phytol. 190:653-666.

Gimenez-Ibanez, S., Boter, M., Fernández-Barbero, G., Chini, A., Rathjen, J. P., and Solano, R. 2014. The bacterial effector HopX1 targets JAZ transcriptional repressors to activate jasmonate signaling and promote infection in Arabidopsis. PLoS Biol. 12:e1001792.

Goritschnig, S., Krasileva, K. V., Dahlbeck, D., and Staskawicz, B. J. 2012. Computational prediction and molecular characterization of an oomycete effector and the cognate Arabidopsis resistance gene. PLoS Genet. 8:e1002502.

Goss, E. M., Press, C. M., and Grünwald, N. J. 2013. Evolution of RXLRclass effectors in the oomycete plant pathogen Phytophthora ramorum. PLoS ONE 8:e79347.

Haas, B. J., Kamoun, S., Zody, M. C., Jiang, R. H., Handsaker, R. E., Cano, L. M., Grabherr, M., Kodira, C. D., Raffaele, S., Torto-Alalibo, T., Bozkurt, T. O., Ah-Fong, A. M., Alvarado, L., Anderson, V. L., Armstrong, M. R., Avrova, A., Baxter, L., Beynon, J., Boevink, P. C., Bollmann, S. R., Bos, J. I., Bulone, V., Cai, G., Cakir, C., Carrington,
J. C., Chawner, M., Conti, L., Costanzo, S., Ewan, R., Fahlgren, N., Fischbach, M. A., Fugelstad, J., Gilroy, E. M., Gnerre, S., Green, P. J., Grenville-Briggs, L. J., Griffith, J., Grünwald, N. J., Horn, K., Horner, N. R., Hu, C. H., Huitema, E., Jeong, D. H., Jones, A. M., Jones, J. D., Jones, R. W., Karlsson, E. K., Kunjeti, S. G., Lamour, K., Liu, Z., Ma, L., Maclean, D., Chibucos, M. C., McDonald, H., McWalters, J., Meijer, H. J., Morgan, W., Morris, P. F., Munro, C. A., O’Neill, K., OspinaGiraldo, M., Pinzón, A., Pritchard, L., Ramsahoye, B., Ren, Q., Restrepo, S., Roy, S., Sadanandom, A., Savidor, A., Schornack, S., Schwartz, D. C., Schumann, U. D., Schwessinger, B., Seyer, L., Sharpe, T., Silvar, C., Song, J., Studholme, D. J., Sykes, S., Thines, M., van de Vondervoort, P. J., Phuntumart, V., Wawra, S., Weide, R., Win, J., Young, C., Zhou, S., Fry, W., Meyers, B. C., van West, P., Ristaino, J., Govers, F., Birch, P. R., Whisson, S. C., Judelson, H. S., and Nusbaum, C. 2009 Genome sequence and analysis of the Irish potato famine pathogen Phytophthora infestans. Nature 461:393-398.

Hogenhout, S. A., Van der Hoorn, R. A., Terauchi, R., and Kamoun, S. 2009. Emerging concepts in effector biology of plant-associated organisms. Mol. Plant-Microbe Interact. 22:115-122.

Janjusevic, R., Abramovitch, R. B., Martin, G. B., and Stebbins, C. E. 2006 A bacterial inhibitor of host programmed cell death defenses is an E3 ubiquitin ligase. Science 311:222-226.

Jiang, R. H., de Bruijn, I., Haas, B. J., Belmonte, R., Löbach, L., Christie, J., van den Ackerveken, G., Bottin, A., Bulone, V., Díaz-Moreno, S. M., Dumas, B., Fan, L., Gaulin, E., Govers, F., Grenville-Briggs, L. J., Horner, N. R., Levin, J. Z., Mammella, M., Meijer, H. J., Morris, P., Nusbaum, C., Oome, S., Phillips, A. J., van Rooyen, D., Rzeszutek, E., Saraiva, M., Secombes, C. J., Seidl, M. F., Snel, B., Stassen, J. H., Sykes, S., Tripathy, S., van den Berg, H., Vega-Arreguin, J. C., Wawra, S., Young, S. K., Zeng, Q., Dieguez-Uribeondo, J., Russ, C., Tyler, B. M. and van West, P. 2013a. Distinctive expansion of potential virulence genes in the genome of the oomycete fish pathogen Saprolegnia parasitica. PLoS Genet. 9:e1003272.

Jiang, R. H., Tripathy, S., Govers, F., and Tyler, B. M. 2008. RXLR effector reservoir in two Phytophthora species is dominated by a single rapidly evolving superfamily with more than 700 members. Proc. Natl. Acad. Sci. U.S.A. 105:4874-4879.

Jiang, R. H., and Tyler, B. M. 2012. Mechanisms and evolution of virulence in oomycetes. Annu. Rev. Phytopathol. 50:295-318.

Jiang, S., Yao, J., Ma, K. W., Zhou, H., Song, J., He, S. Y., and Ma, W. 2013b. Bacterial effector activates jasmonate signaling by directly targeting JAZ transcriptional repressors. PLoS Pathog. 9:e1003715.

Kale, S. D., Gu, B., Capelluto, D. G., Dou, D., Feldman, E., Rumore, A. Arredondo, F. D., Hanlon, R., Fudal, I., Rouxel, T., Lawrence, C. B. Shan, W., and Tyler, B. M. 2010. External lipid PI3P mediates entry of eukaryotic pathogen effectors into plant and animal host cells. Cell 142: 284-295.

Kale, S. D., and Tyler, B. M. 2011. Entry of oomycete and fungal effectors into plant and animal host cells. Cell. Microbiol. 13:1839-1848.

Kaschani, F., Shabab, M., Bozkurt, T., Shindo, T., Schornack, S., Gu, C., Ilyas, M., Win, J., Kamoun, S., and van der Hoorn, R. A. L. 2010. An effector-targeted protease contributes to defense against Phytophthora infestans and is under diversifying selection in natural hosts. Plant Physiol. 154:1794-1804.

Kasuga, T., and Gijzen, M. 2013. Epigenetics and the evolution of virulence. Trends Microbiol. 21:575-582.

Kelley, B. S., Lee, S. J., Damasceno, C. M., Chakravarthy, S., Kim, B. D., Martin, G. B., and Rose, J. K. 2010. A secreted effector protein (SNE1) from Phytophthora infestans is a broadly acting suppressor of programmed cell death. Plant J. 62:357-366.

Kemen, E., Gardiner, A., Schultz-Larsen, T., Kemen, A. C., Balmuth, A. L., Robert-Seilaniantz, A., Bailey, K., Holub, E., Studholme, D. J., Maclean, D., and Jones, J. D. G. 2011. Gene gain and loss during evolution of obligate parasitism in the white rust pathogen of Arabidopsis thaliana. PLoS Biol. 9:e1001094.

Kemen, E., and Jones, J. D. 2012. Obligate biotroph parasitism: Can we link genomes to lifestyles? Trends Plant Sci. 17:448-457.

Koeck, M., Hardham, A. R., and Dodds, P. N. 2011. The role of effectors of biotrophic and hemibiotrophic fungi in infection. Cell. Microbiol. 13: 1849-1857.

Krajaejun, T., Khositnithikul, R., Lerksuthirat, T., Lowhnoo, T., Rujirawat, T., Petchthong, T., Yingyong, W., Suriyaphol, P., Smittipat, N., Juthayothin, T., Phuntumart, V., and Sullivan, T. D. 2011. Expressed sequence tags reveal genetic diversity and putative virulence factors of the pathogenic oomycete Pythium insidiosum. Fungal Biol. 115: 683-696.

Krajaejun, T., Lerksuthirat, T., Garg, G., Lowhnoo, T., Yingyong, W., Khositnithikul, R., Tangphatsornruang, S., Suriyaphol, P., Ranganathan, 
S., and Sullivan, T. D. 2014. Transcriptome analysis reveals pathogenicity and evolutionary history of the pathogenic oomycete Pythium insidiosum. Fungal Biol. 118:640-653.

Krasileva, K. V., Dahlbeck, D., and Staskawicz, B. J. 2010. Activation of an Arabidopsis resistance protein is specified by the in planta association of its leucine-rich repeat domain with the cognate oomycete effector. Plant Cell 22:2444-2458.

Lee, C., Chronis, D., Kenning, C., Peret, B., Hewezi, T., Davis, E. L., Baum, T. J., Hussey, R., Bennett, M., and Mitchum, M. G. 2011. The novel cyst nematode effector protein 19C07 interacts with the Arabidopsis auxin influx transporter LAX3 to control feeding site development. Plant Physiol. 155:866-880.

Lee, H. A., Kim, S. Y., Oh, S. K., Yeom, S. I., Kim, S. B., Kim, M. S., Kamoun, S., and Choi, D. 2014. Multiple recognition of RXLR effectors is associated with nonhost resistance of pepper against Phytophthora infestans. New Phytol. 203:926-938.

Leonelli, L., Pelton, J., Schoeffler, A., Dahlbeck, D., Berger, J., Wemmer, D. E., and Staskawicz, B. 2011. Structural elucidation and functional characterization of the Hyaloperonospora arabidopsidis effector protein ATR13. PLoS Pathog. 7:e1002428.

Lévesque, C. A., Brouwer, H., Cano, L., Hamilton, J. P., Holt, C., Huitema, E., Raffaele, S., Robideau, G. P., Thines, M., Win, J., Zerillo, M. M. Beakes, G. W., Boore, J. L., Busam, D., Dumas, B., Ferriera, S., Fuerstenberg, S. I., Gachon, C. M., Gaulin, E., Govers, F., GrenvilleBriggs, L., Horner, N., Hostetler, J., Jiang, R. H., Johnson, J., Krajaejun, T., Lin, H., Meijer, H. J., Moore, B., Morris, P., Phuntmart, V., Puiu, D., Shetty, J., Stajich, J. E., Tripathy, S., Wawra, S., van West, P., Whitty, B. R., Coutinho, P. M., Henrissat, B., Martin, F., Thomas, P. D., Tyler, B. M., De Vries, R. P., Kamoun, S., Yandell, M., Tisserat, N., and Buell, C. R. 2010. Genome sequence of the necrotrophic plant pathogen Pythium ultimum reveals original pathogenicity mechanisms and effector repertoire. Genome Biol. 11:R73.

Links, M. G., Holub, E., Jiang, R. H., Sharpe, A. G., Hegedus, D., Beynon, E., Sillito, D., Clarke, W. E., Uzuhashi, S., and Borhan, M. H. 2011. De novo sequence assembly of Albugo candida reveals a small genome relative to other biotrophic oomycetes. BMC Genomics 12:503.

McDowell, J. M. 2011. Genomes of obligate plant pathogens reveal adaptations for obligate parasitism. Proc. Natl. Acad. Sci. U.S.A. 108: 8921-8922.

McLellan, H., Boevink, P. C., Armstrong, M. R., Pritchard, L., Gomez, S., Morales, J., Whisson, S. C., Beynon, J. L., and Birch, P. R. 2013. An RxLR effector from Phytophthora infestans prevents re-localisation of two plant NAC transcription factors from the endoplasmic reticulum to the nucleus. PLoS Pathog. 9:e1003670.

Mukhtar, M. S., Carvunis, A. R., Dreze, M., Epple, P., Steinbrenner, J., Moore, J., Tasan, M., Galli, M., Hao, T., Nishimura, M. T., Pevzner, S. J., Donovan, S. E., Ghamsari, L., Santhanam, B., Romero, V., Poulin, M. M., Gebreab, F., Gutierrez, B. J., Tam, S., Monachello, D., Boxem, M., Harbort, C. J., McDonald, N., Gai, L., Chen, H., He, Y., Vandenhaute, J., Roth, F. P., Hill, D. E., Ecker, J. R., Vidal, M., Beynon, J., Braun, P., and Dangl, J. L.; European Union Effectoromics Consortium. 2011. Independently evolved virulence effectors converge onto hubs in a plant immune system network. Science 333:596-601.

Munkvold, K. R., and Martin, G. B. 2009. Advances in experimental methods for the elucidation of Pseudomonas syringae effector function with a focus on AvrPtoB. Mol. Plant Pathol. 10:777-793.

Na, R., Yu, D., Chapman, B. P., Zhang, Y., Kuflu, K., Austin, R., Qutob, D., Zhao, J., Wang, Y., and Gijzen, M. 2014. Genome re-sequencing and functional analysis places the Phytophthora sojae avirulence genes Avrlc and Avrla in a tandem repeat at a single locus. PLoS ONE 9: e89738.

Na, R., Yu, D., Qutob, D., Zhao, J., and Gijzen, M. 2013. Deletion of the Phytophthora sojae avirulence gene Avrld causes gain of virulence on Rps1d. Mol. Plant-Microbe Interact. 26:969-976.

Oh, S. K., Young, C., Lee, M., Oliva, R., Bozkurt, T. O., Cano, L. M., Win, J., Bos, J. I., Liu, H. Y., van Damme, M., Morgan, W., Choi, D., Van der Vossen, E. A., Vleeshouwers, V. G., and Kamoun, S. 2009. In planta expression screens of Phytophthora infestans RXLR effectors reveal diverse phenotypes, including activation of the Solanum bulbocastanum disease resistance protein Rpi-blb2. Plant Cell 21: 2928-2947.

Oliva, R. F., Cano, L., Raffaele, S., Win, J., Bozkurt, T. O., Belhaj, K., Oh, S., Thines, M., and Kamoun, S. 2015. A recent expansion of the RXLR effector gene Avrblb2 is maintained in global populations of Phytophthora infestans indicating different contributions to virulence. Mol. Plant-Microbe Interact. 27:901-912.

Pais, M., Win, J., Yoshida, K., Etherington, G. J., Cano, L. M., Raffaele, S., Banfield, M. J., Jones, A., Kamoun, S., and Saunders, D. G. 2013. From pathogen genomes to host plant processes: The power of plant parasitic oomycetes. Genome Biol. 14:211.

Pel, M. J., Wintermans, P. C., Cabral, A., Robroek, B. J., Seidl, M. F., Bautor, J., Parker, J. E., Van den Ackerveken, G., and Pieterse, C. M. 2014. Functional analysis of Hyaloperonospora arabidopsidis RXLR effectors. PLoS ONE 9:e110624.

Petre, B., and Kamoun, S. 2014. How do filamentous pathogens deliver effector proteins into plant cells? PLoS Biol. 12:e1001801.

Pritchard, L., and Birch, P. 2011. A systems biology perspective on plantmicrobe interactions: Biochemical and structural targets of pathogen effectors. Plant Sci. 180:584-603.

Qiao, Y., Liu, L., Xiong, Q., Flores, C., Wong, J., Shi, J., Wang, X., Liu, X., Xiang, Q., Jiang, S., Zhang, F., Wang, Y., Judelson, H. S., Chen, X., and $\mathrm{Ma}, \mathrm{W} .2013$. Oomycete pathogens encode RNA silencing suppressors. Nat. Genet. 45:330-333.

Qiao, Y., Shi, J., Zhai, Y., Hou, Y., and Ma, W. 2015. Phytophthora effector targets a novel component of small RNA pathway in plants to promote infection. Proc. Natl. Acad. Sci. U.S.A. 112:5850-5855.

Qutob, D., Chapman, B. P., and Gijzen, M. 2013. Transgenerational gene silencing causes gain of virulence in a plant pathogen. Nat. Commun. 4: 1349

Qutob, D., Tedman-Jones, J., Dong, S., Kuflu, K., Pham, H., Wang, Y., Dou, D., Kale, S. D., Arredondo, F. D., Tyler, B. M., and Gijzen, M. 2009 Copy number variation and transcriptional polymorphisms of Phytophthora sojae RXLR effector genes Avrla and Avr3a. PLoS ONE 4:e5066.

Raffaele, S., Farrer, R. A., Cano, L. M., Studholme, D. J., MacLean, D., Thines, M., Jiang, R. H., Zody, M. C., Kunjeti, S. G., Donofrio, N. M., Meyers, B. C. Nusbaum, C., and Kamoun, S. 2010. Genome evolution following host jumps in the Irish potato famine pathogen lineage. Science 330:1540-1543.

Raffaele, S., and Kamoun, S. 2012. Genome evolution in filamentous plant pathogens: Why bigger can be better. Nat. Rev. Microbiol. 10:417-430.

Rehmany, A. P., Gordon, A., Rose, L. E., Allen, R. L., Armstrong, M. R., Whisson, S. C., Kamoun, S., Tyler, B. M., Birch, P. R., and Beynon, J. L. 2005. Differential recognition of highly divergent downy mildew avirulence gene alleles by $R P P 1$ resistance genes from two Arabidopsis lines. Plant Cell 17:1839-1850.

Saunders, D. G., Breen, S., Win, J., Schornack, S., Hein, I., Bozkurt, T. O., Champouret, N., Vleeshouwers, V. G., Birch, P. R., Gilroy, E. M., and Kamoun, S. 2012. Host protein BSL1 associates with Phytophthora infestans RXLR effector AVR2 and the Solanum demissum immune receptor R2 to mediate disease resistance. Plant Cell 24:3420-3434.

Schornack, S., Huitema, E., Cano, L. M., Bozkurt, T. O., Oliva, R., Van Damme, M., Schwizer, S., Raffaele, S., Chaparro-Garcia, A., Farrer, R., Segretin, M. E., Bos, J., Haas, B. J., Zody, M. C., Nusbaum, C., Win, J., Thines, M., and Kamoun, S. 2009. Ten things to know about oomycete effectors. Mol. Plant Pathol. 10:795-803.

Segretin, M. E., Pais, M., Franceschetti, M., Chaparro-Garcia, A., Bos, J. I., Banfield, M. J., and Kamoun, S. 2014. Single amino acid mutations in the potato immune receptor R3a expand response to Phytophthora effectors. Mol. Plant-Microbe Interact. 27:624-637.

Senchou, V., Weide, R., Carrasco, A., Bouyssou, H., Pont-Lezica, R., Govers, F., and Canut, H. 2004. High affinity recognition of a Phytophthora protein by Arabidopsis via an RGD motif. Cell. Mol. Life Sci. 61:502-509.

Shan, W., Cao, M., Leung, D., and Tyler, B. M. 2004. The Avr1b locus of Phytophthora sojae encodes an elicitor and a regulator required for avirulence on soybean plants carrying resistance gene $R p s 1 b$. Mol. PlantMicrobe Interact. 17:394-403.

Sohn, K. H., Lei, R., Nemri, A., and Jones, J. D. 2007. The downy mildew effector proteins ATR1 and ATR13 promote disease susceptibility in Arabidopsis thaliana. Plant Cell 19:4077-4090.

Song, T., Kale, S. D., Arredondo, F. D., Shen, D., Su, L., Liu, L., Wu, Y., Wang, Y., Dou, D., and Tyler, B. M. 2013. Two RxLR avirulence genes in Phytophthora sojae determine soybean Rps1k-mediated disease resistance. Mol. Plant-Microbe Interact. 26:711-720.

Stassen, J. H., den Boer, E., Vergeer, P. W., Andel, A., Ellendorff, U., Pelgrom, K., Pel, M., Schut, J., Zonneveld, O., Jeuken, M. J., and Van den Ackerveken, G. 2013. Specific in planta recognition of two GKLR proteins of the downy mildew Bremia lactucae revealed in a large effector screen in lettuce. Mol. Plant-Microbe Interact. 26:1259-1270.

Stassen, J. H., and Van den Ackerveken, G. 2011. How do oomycete effectors interfere with plant life? Curr. Opin. Plant Biol. 14:407-414.

Steinbrenner, A. D., Goritschnig, S., and Staskawicz, B. J. 2015. Recognition and activation domains contribute to allele-specific responses of an Arabidopsis NLR receptor to an oomycete effector protein. PLoS Pathog. 11:e1004665.

Thines, M. 2014. Phylogeny and evolution of plant pathogenic oomycetes: A global overview. Eur. J. Plant Pathol. 138:431-447. 
Thines, M., and Kamoun, S. 2010. Oomycete-plant coevolution: Recent advances and future prospects. Curr. Opin. Plant Biol. 13:427-433.

Thines, B., Katsir, L., Melotto, M., Niu, Y., Mandaokar, A., Liu, G., Nomura, K., He, S. Y., Howe, G. A., and Browse, J. 2007. JAZ repressor proteins are targets of the $\mathrm{SCF}(\mathrm{COI} 1)$ complex during jasmonate signalling. Nature 448:661-665.

Tian, M., Win, J., Savory, E., Burkhardt, A., Held, M., Brandizzi, F., and Day, B. 2011. 454 Genome sequencing of Pseudoperonospora cubensis reveals effector proteins with a QXLR translocation motif. Mol. PlantMicrobe Interact. 24:543-553.

Tyler, B., and Gijzen, M. 2014. The Phytophthora sojae Genome Sequence: Foundation for a Revolution. Pages 133-157. in: Genomics of PlantAssociated Fungi and Oomycetes: Dicot Pathogens, R.A. Dean, A. Lichens-Park, and C. Kole, eds. Springer-Verlag, Heidelberg, Germany.

Tyler, B. M., Kale, S. D., Wang, Q., Tao, K., Clark, H. R., Drews, K., Antignani, V., Rumore, A., Hayes, T., Plett, J. M., Fudal, I., Gu, B., Chen, Q., Affeldt, K. J., Berthier, E., Fischer, G. J., Dou, D., Shan, W., Keller, N. P., Martin, F., Rouxel, T., and Lawrence, C. B. 2013. Microbeindependent entry of oomycete RxLR effectors and fungal RxLR-like effectors into plant and animal cells is specific and reproducible. Mol. Plant-Microbe Interact. 26:611-616.

Tyler, B. M., Tripathy, S., Zhang, X., Dehal, P., Jiang, R. H., Aerts, A., Arredondo, F. D., Baxter, L., Bensasson, D., Beynon, J. L., Chapman, J., Damasceno, C. M., Dorrance, A. E., Dou, D., Dickerman, A. W., Dubchak, I. L., Garbelotto, M., Gijzen, M., Gordon, S. G., Govers, F., Grunwald, N. J., Huang, W., Ivors, K. L., Jones, R. W., Kamoun, S., Krampis, K., Lamour, K. H., Lee, M. K., McDonald, W. H., Medina, M., Meijer, H. J., Nordberg, E. K., Maclean, D. J., Ospina-Giraldo, M. D., Morris, P. F., Phuntumart, V., Putnam, N. H., Rash, S., Rose, J. K., Sakihama, Y., Salamov, A. A., Savidor, A., Scheuring, C. F., Smith, B. M., Sobral, B. W., Terry, A., Torto-Alalibo, T. A., Win, J., Xu, Z., Zhang, H., Grigoriev, I. V., Rokhsar, D. S., and Boore, J. L. 2006. Phytophthora genome sequences uncover evolutionary origins and mechanisms of pathogenesis. Science 313:1261-1266.

van Poppel, P. M., Guo, J., van de Vondervoort, P. J., Jung, M. W., Birch, P. R., Whisson, S. C., and Govers, F. 2008. The Phytophthora infestans avirulence gene Avr4 encodes an RXLR-dEER effector. Mol. PlantMicrobe Interact. 21:1460-1470.

Vega-Arreguín, J. C., Jalloh, A., Bos, J. I., and Moffett, P. 2014. Recognition of an Avr3a homologue plays a major role in mediating nonhost resistance to Phytophthora capsici in Nicotiana species. Mol. Plant-Microbe Interact. 27:770-780.

Vleeshouwers, V. G., and Oliver, R. P. 2014. Effectors as tools in disease resistance breeding against biotrophic, hemibiotrophic, and necrotrophic plant pathogens. Mol. Plant-Microbe Interact. 27:196-206.

Vleeshouwers, V. G., Raffaele, S., Vossen, J. H., Champouret, N., Oliva, R., Segretin, M. E., Rietman, H., Cano, L. M., Lokossou, A., Kessel, G., Pel, M. A., and Kamoun, S. 2011. Understanding and exploiting late blight resistance in the age of effectors. Annu. Rev. Phytopathol. 49:507-531.

Wang, Q., Han, C., Ferreira, A. O., Yu, X., Ye, W., Tripathy, S., Kale, S. D., Gu, B., Sheng, Y., Sui, Y., Wang, X., Zhang, Z., Cheng, B., Dong, S., Shan, W., Zheng, X., Dou, D., Tyler, B. M., and Wang, Y. 2011. Transcriptional programming and functional interactions within the Phytophthora sojae RXLR effector repertoire. Plant Cell 23:2064-2086.

Wang, X., Boevink, P., McLellan, H., Armstrong, M., Bukharova, T., Qin, Z., and Birch, P. R. 2015. A host KH RNA binding protein is a susceptibility factor targeted by an RXLR effector to promote late blight disease. Mol. Plant Online doi:10.1016/j.molp.2015.04.012. Published online.

Wawra, S., Belmonte, R., Löbach, L., Saraiva, M., Willems, A., and van West, P. 2012. Secretion, delivery and function of oomycete effector proteins. Curr. Opin. Microbiol. 15:685-691.
Wawra, S., Djamei, A., Albert, I., Nürnberger, T., Kahmann, R., and van West, P. 2013. In vitro translocation experiments with RxLR-reporter fusion proteins of Avr1b from Phytophthora sojae and AVR3a from Phytophthora infestans fail to demonstrate specific autonomous uptake in plant and animal cells. Mol. Plant-Microbe Interact. 26: 528-536.

Wessling, R., Epple, P., Altmann, S., He, Y., Yang, L., Henz, S. R., McDonald, N., Wiley, K., Bader, K. C., Gläßer, C., Mukhtar, M. S., Haigis, S., Ghamsari, L., Stephens, A. E., Ecker, J. R., Vidal, M., Jones, J. D., Mayer, K. F., Ver Loren van Themaat, E., Weigel, D., SchulzeLefert, P., Dangl, J. L., Panstruga, R., and Braun, P. 2014. Convergent targeting of a common host protein-network by pathogen effectors from three kingdoms of life. Cell Host Microbe 16:364-375.

Whisson, S., Vetukuri, R., Avrova, A., and Dixelius, C. 2012. Can silencing of transposons contribute to variation in effector gene expression in Phytophthora infestans? Mob. Genet. Elements 2:110-114.

Whisson, S. C., Boevink, P. C., Moleleki, L., Avrova, A. O., Morales, J. G. Gilroy, E. M., Armstrong, M. R., Grouffaud, S., van West, P., Chapman, S., Hein, I., Toth, I. K., Pritchard, L., and Birch, P. R. 2007. A translocation signal for delivery of oomycete effector proteins into host plant cells. Nature 450:115-118.

Win, J., Chaparro-Garcia, A., Belhaj, K., Saunders, D. G., Yoshida, K. Dong, S., Schornack, S., Zipfel, C., Robatzek, S., Hogenhout, S. A., and Kamoun, S. 2012b. Effector biology of plant-associated organisms: Concepts and perspectives. Cold Spring Harb. Symp. Quant. Biol. 77: 235-247.

Win, J., Krasileva, K. V., Kamoun, S., Shirasu, K., Staskawicz, B. J., and Banfield, M. J. 2012a. Sequence divergent RXLR effectors share a structural fold conserved across plant pathogenic oomycete species. PLoS Pathog. 8:e1002400.

Wong, J., Gao, L., Yang, Y., Zhai, J., Arikit, S., Yu, Y., Duan, S., Chan, V., Xiong, Q., Yan, J., Li, S., Liu, R., Wang, Y., Tang, G., Meyers, B. C., Chen, X., and Ma, W. 2014. Roles of small RNAs in soybean defense against Phytophthora sojae infection. Plant J. 79:928-940.

Wroblewski, T., Tomczak, A., and Michelmore, R. 2005. Optimization of Agrobacterium-mediated transient assays of gene expression in lettuce, tomato and Arabidopsis. Plant Biotechnol. J. 3:259-273.

Xiong, Q., Ye, W., Choi, D., Wong, J., Qiao, Y., Tao, K., Wang, Y., and Ma, W. 2014. Phytophthora suppressor of RNA silencing 2 is a conserved RxLR effector that promotes infection in soybean and Arabidopsis thaliana. Mol. Plant-Microbe Interact. 27:1379-1389.

Yaeno, T., Li, H., Chaparro-Garcia, A., Schornack, S., Koshiba, S., Watanabe, S., Kigawa, T., Kamoun, S., and Shirasu, K. 2011. Phosphatidylinositol monophosphate-binding interface in the oomycete RXLR effector AVR3a is required for its stability in host cells to modulate plant immunity. Proc. Natl. Acad. Sci. U.S.A. 108: 14682-14687.

Yin, W., Dong, S., Zhai, L., Lin, Y., Zheng, X., and Wang, Y. 2013. The Phytophthora sojae Avrld gene encodes an RxLR-dEER effector with presence and absence polymorphisms among pathogen strains. Mol. Plant-Microbe Interact. 26:958-968.

Zheng, X., McLellan, H., Fraiture, M., Liu, X., Boevink, P. C., Gilroy, E. M., Chen, Y., Kandel, K., Sessa, G., Birch, P. R., and Brunner, F. 2014 Functionally redundant RXLR effectors from Phytophthora infestans act at different steps to suppress early flg22-triggered immunity. PLoS Pathog. 10:e1004057.

\section{AUTHOR-RECOMMENDED INTERNET RESOURCE}

Fungi DB database: www.fungiDB.org 